\title{
The WTO in an Era of Preferential Trade Agreements: Thick and Thin Institutions in Global Trade Governance
}

\author{
SILKE TROMMER * \\ University of Manchester
}

\begin{abstract}
This article examines how fragmentation of the global trade regime into preferential agreements, built on a multilateral baseline of World Trade Organization (WTO) rules, affects trade governance. The analysis relies on 105 interviews with trade policy professionals in core WTO members and a conceptual distinction between 'thick' and 'thin' institutionalism to capture institutional changes in the global trade governance architecture. The WTO's thick institutionalism facilitates institutionalized interactions among members of the trade policy community that are essential for transparency and dialogue and the rule of law character of the trade regime. It secures the continued belief of trade policy professionals in the WTO's centrality in trade governance. The thin institutionalism of the network of preferential agreements spells the return to à la carte forms of trade governance and benefits those with the technical and political capacity to successfully navigate the fragmented governance architecture.

Ongoing institutional transformations shift global trade governance away from rules-based back to more power-based forms.
\end{abstract}

\section{Introduction}

Global trade relations today are embedded in an institutionally fragmented governance architecture that combines a uniform base of multilateral rules with a web of bilateral and regional superstructures. Following the World Trade Organization (WTO)'s 2015 Nairobi Ministerial Conference, negotiations on pending issues from the Doha Development Agenda (DDA) continue in Geneva. Rule-making on $\mathrm{WTO}+$ and $\mathrm{WTO}++$ topics proliferates through preferential trade agreements (PTAs). By June 2016, 635 PTAs had been notified to the WTO Secretariat of which $10 \%$ are customs unions and $90 \%$ are free trade agreements (WTO,

\footnotetext{
*Email: silke.trommer@manchester.ac.uk

This project was supported by the Australian Research Council (Discovery Grant 120101634). Professor Ann Capling, University of Melbourne, designed the research project and secured research funding. We collectively built the sample and she participated in field work in India and China. I am deeply indebted to her for her mentorship and grateful for our continued friendship. I would also like to thank Marc Froese, Martin Björklund, and the reviewers for excellent feedback provided.
} 
2016a). In light of the political events of 2016, notably the British referendum on European Union (EU) membership and the United States (US) presidential election, hopes that the current generation of megaregional negotiations could produce building blocs for a more unified trade regime hang in the air. How fragmentation of the governance architecture affects world trade politics is one key question for the future of the WTO, of the trade regime, and of multilateralism more broadly.

Trade multilateralism is seen as economically and politically superior to PTAs in the literature (Bhagwati, 2008; Capling and Ravenhill, 2011). Ample scholarship exists to explain why governments nonetheless negotiate networks of bilateral trade deals (see, e.g., Mercurio, 2009; Evenett, 2014). Vinod Aggarwal and Simon Evenett (2013) highlight four changing economic and political parameters as root causes of fragmentation. First, developing countries insist that the terms of multilateral trade deals be redrawn in their favor to correct perceived biased outcomes from the 1986-1994 Uruguay Round. Second, developing countries have gained negotiating power in the WTO, 'and cannot so easily be pressured, marginalized or ignored by richer members' (Aggarwal and Evenett, 2013: 6). Third, the US and the EU have come to see PTAs as superior tools for the pursuit of their commercial interests. Fourth, the established consensus concerning government intervention and industrial policy has been undone in view of the economic successes of emerging markets and the aftermath of the Global Financial Crisis (Aggwaral and Evenett, 2013). Such analysis conceptualizes states as unified actors in global trade governance that hold exogenously determined political and economic interests, and that shift between preferential and multilateral policy venues according to where they expect to pursue their goals most successfully.

From this theoretical vantage point, the inability to conclude the Doha Round is often seen as compelling evidence for the decline of trade multilateralism. Some scholars have begun challenging this assessment, for example by placing trade multilateralism in a longer historical perspective (Muzaka and Bishop, 2015), or by examining how disputes are channeled from preferential deals to the multilateral level (Froese, 2016). This article joins this growing body of literature by supplementing theoretical insights with an analysis of the views of trade policy communities in core WTO members. Examining the perceptions of different trade policy constituencies in different countries, this article argues that ongoing transformations in global trade governance are more complex than a simple death-of-theWTO hypothesis acknowledges. The following reflection offered by a Canadian trade official in an interview illustrates this point: 'equat[ing] the breakdown of the Doha Round with the failure and demise of the WTO ... betrays a lack of understanding of what the WTO does, how many functions are integral to the WTO, and how much value WTO members attach to those functions'.

This article makes both empirical and theoretical contributions to the literature on institutional evolutions in the global trade system in particular, and on multilateral governance in general. Empirically, it does not directly explore trade professionals' views on the failures of the Doha Round, or on how multilateral 
negotiations may be re-launched, although the analysis holds relevance for these questions. Scrutinizing the understandings of policy practitioners allows revisiting assumptions about their interests and motivations for behavior in trade governance. The empirical finding that the majority of interviewees in principle believe the WTO to maintain centrality in the global trading system raises questions about how ongoing institutional transformations in global trade governance are to be conceptualized in the literature. Simply put - if global trade powers have come to see PTAs as superior tools for pursuing their commercial interests, why do they continue participating in multilateral governance in Geneva? This study suggests that trade policy professionals conceive of the global trade governance architecture holistically, and formulate and pursue their interests with both multilateral and bilateral legal and institutional structures in mind. Yet, with the exception of the building bloc/stumbling bloc debate (see Baldwin and Seghezza, 2010), the literature tends to analyze multilateral and bilateral initiatives separately. This leaves gaps in our knowledge about the impact of legal and institutional fragmentation on the politics of international trade relations. This article attempts to fill these gaps. Collectively, interviewees drew attention to the role that human and financial resource constraints play in navigating the global trade governance architecture and to the institutional limitations of PTA-based dispute settlement that threaten to undermine the rule of law character of the trade regime.

This article relies on 105 interviews conducted with members of trade policy communities in Brazil, Canada, China, the EU, India, South Africa, the US, and Geneva from March 2013 through April 2015. The sample includes representatives from public trade institutions, the private sector (business and agriculture), labor, civil society, as well as academic experts, research institutes, and think tanks. It was built through professional networks acquired during previous research (Capling and Low, 2010; Trommer, 2014) and snowballing techniques. Interviewees participated in semi-structured, open-ended interviews in a personal capacity. As most participants continue to engage with trade policy processes professionally at the time of writing, anonymity was guaranteed to informants.

Table 1 shows interviewees by WTO member, timeline of the research, and type of actor.

The sample provides a snapshot of prevalent opinions among 105 trade policy practitioners across seven WTO members and a number of international organizations at a particular historical moment, that is to say between 2013 and 2015 . Resources to expand the research beyond this group have not been available. Although care needs to be exercised in making theoretical generalizations based on non-representative samples, the list provided in Appendix 1 demonstrates the centrality of the organizations, with which interviewees were affiliated, to domestic trade politics and global trade governance.

The sample may contain a selection bias. Since informants agreed to participate in a research project on the WTO, it is arguably unsurprising that they tended to show positive attitudes towards multilateral trade cooperation in principle. 
Table 1. Interviewees

\begin{tabular}{lcccccr}
\hline \hline Country (Year of field work) & Officials & $\begin{array}{l}\text { Private } \\
\text { Sector }\end{array}$ & Labor & $\begin{array}{l}\text { Civil } \\
\text { society }\end{array}$ & $\begin{array}{l}\text { Academics \& } \\
\text { think tanks }\end{array}$ & Total \\
\hline Brazil (2013) & 5 & 2 & 1 & 2 & 4 & $\mathbf{1 4}$ \\
Canada (2014) & 8 & 3 & 1 & 2 & 3 & $\mathbf{1 7}$ \\
China (2013) & 3 & 0 & 0 & 0 & 8 & $\mathbf{1 1}$ \\
EU (2013) & 4 & 7 & 2 & 2 & 0 & $\mathbf{1 5}$ \\
India (2015) & 2 & 3 & 0 & 3 & 4 & $\mathbf{1 2}$ \\
South Africa (2013) & 4 & 3 & 1 & 1 & 5 & $\mathbf{1 4}$ \\
USA (2014) & 3 & 5 & 1 & 1 & 6 & $\mathbf{1 6}$ \\
International (2014) & 2 & 0 & 2 & 0 & 2 & $\mathbf{6}$ \\
Total & 31 & $\mathbf{2 3}$ & $\mathbf{8}$ & $\mathbf{1 1}$ & 32 & $\mathbf{1 0 5}$ \\
\hline \hline
\end{tabular}

However, this constitutes a relevant finding, not least because it jars with common assumptions in the literature about a loss of interest in multilateral governance among key actors in global trade politics. Irrespective of whether participants estimated that the WTO was an institution in crisis, irrelevant, or fundamentally misguided in its policy approach, interviewees expressed strong convictions that multilateral cooperation was in principle the first best option for arranging international trade relations in the world today.

Theoretically, this article emphasizes both the role of ideas and perceptions and the non-unified nature of states in the global trading system by shining light on the views of different trade policy constituencies in a number of core trading nations. It engages the literature that sees the growing number of institutional venues in global governance in a critical light (Alter and Meunier, 2009; Papa, 2015). Daniel Drezner suggests that 'institutional thickness weakens global governance structures' (Drezner, 2013: 280), because multiplying institutional venues impairs the power of existing institutional hubs in world politics. Forum-shopping and conflicting legal mandates corrode regime coherence. Small governments in particular struggle with the financial cost associated with fragmentation (Drezner, 2013). In trade governance, Christina Davis argues that the multiplicity of available trade policy institutions produces 'forum shopping, increased reliance on technical experts, small group environments, and competition among institutions' (Davis, 2009: 25). The analysis conducted here adds the hollowing out of institutional support structures for global trade governance as another element to back the theoretical conclusion that, after a certain point, the proliferation of institutions leads global governance back towards more power-based forms.

Instead of considering the number of institutional venues as an indicator of institutional thickness, the analysis builds on the European public policy literature's distinction between a thick institutionalism, in which institutions shape political actors' understandings of their policy goals and interests through formal and informal norms, standards of behavior, and principles of interaction, and a thin 
perspective on institutions, in which the latter merely provide spaces in which actors exchange their pre-determined interests and enforce agreements where they occur (for a review of thick vs. thin institutionalism in European public policy, see Paraskevopoulos, 2002). This article posits that thick and thin institutionalism are useful concepts for capturing the qualitative differences in governing trade through the WTO and governing trade through the PTA network. It takes a holistic perspective on the global trading system in which PTA-based and multilateral trade governance evolve in an interdependent relationship according to unifying and centrifugal political economic forces within the evolving trade governance architecture. Governance architectures are 'systems of institutions and governance mechanisms in particular areas of world politics' (Biermann et al., 2009: 14), including regime complexes, institutional networks, norms, and principles.

At least two fundamental characteristics make the WTO institutionally thick in ways that PTAs are not. Although both the WTO and the 635+ PTAs may fall within the category of international institutions in a broader, sociological sense, the WTO is an international organization with legal personality, political organs, a seat, and a secretariat. Qualitatively, the WTO is therefore a very different kind of institution than any of the existing PTAs. Its character as an international organization enables it to provide institutional support mechanisms and infrastructures for international trade cooperation that bring the global trade policy community together on a day-to-day basis while maintaining a degree of independence from any single government's trade policy goals. These elements of thick institutionalism are essential for dialogue and transparency among members of the global trade policy to be effective and for facilitating access to dispute settlement in the trade regime.

Thin institutionalism characterizes the PTA network within the global trade governance architecture. As a general rule, PTAs to date remain, simply, international treaties. They create international legal rights and obligations for contracting parties, including the possibility of dispute settlement and arbitration, yet the PTA network does not have a physical epicenter where world trade politics play out on a day-to-day basis. Its policy venues are poly-centric, and do not come equipped with international civil servants, budgets, and headquarters, through which international trade rules are administered, monitored, and enforced independently from their makers. Their dispute settlement provisions remain institutionally incomplete and are therefore unlikely to rival WTO adjudication in reliability, accessibility, and legal certainty. Because the PTA network knows no independent institutional support for the various aspects of international trade cooperation, it cannot replace the institutionalized, thick interactions facilitated, however imperfectly perhaps, by the WTO.

Overall, this article adds two insights to debates on the future of global trade governance and trade multilateralism. First, the poly-centric institutional set-up of the PTA network reduces the quality of political interactions that occur within the global trade policy community. This article shows that trade policy 
professionals rely more substantially on the political organs and institutional infrastructure of the WTO than is typically acknowledged in the literature. This insight holds explanatory potential for members' continuing engagement with the organization, irrespective of the effectiveness of its rule-making function in the immediate term. Trade practitioners consider transparency, enforceability, and uniformity of trade rules to be crucial for global trade governance, and see the PTA network as institutionally limited in this regard. As one informant affiliated with the United States Trade Representative (USTR) Office asserted in the interview: 'the question of whether the multilateral trading system continues to have relevance is bordering on a ridiculous question'.

Second, thin institutionalism is one element of a fragmented global trade governance architecture that dilutes the rules-based character of the global trade system and shifts international trade relations to more power-based modes of interaction. Thin institutionalism hampers the PTAs' ability to provide transparency and dialogue, to deliver accessible and impartial adjudication, and to guarantee uniformity and simplicity of rules. Preferential agreements therefore bring back the political flexibility of an à la carte approach to those rules, that was reduced with the creation of the WTO. While small trading nations and marginal political actors in world trade politics are likely adversely affected, thin institutionalism empowers those in a position to shape PTA content and enforcement. Speaking about the most powerful countries in the trading system, a Canadian business representative suggested that 'there's something about their negotiating culture that's more comfortable in a world based on power, which you would be if you were the most powerful'.

The analysis unfolds over six sections. The next section contrasts scholarly perspectives on the WTO's governance functions with the views of participants to the research. The following sections discuss dialogue and transparency, adjudication of disputes, and the negotiation of trade rules as the three key functions of global trade governance institutions. Each section compares and contrasts scholarly and interview-based insights on how the WTO and the PTA network perform in providing these functions. The final section summarizes findings and suggests avenues for future research.

\section{The purposes and functions of the WTO}

Lack of consensus on the WTO's political purpose characterizes academic and policy debates. This section briefly reviews the theoretical debate and presents the responses provided in the interviews. Although the trade policy community appears divided on what policy goals the WTO ought to pursue, the data show a strong consensus among trade policy professionals that the transparency, enforceability, and uniformity of global trade rules provided by the WTO are key for global trade governance to be fair and effective. This includes sets of actors that 
have been suspected to disfavor trade multilateralism, or to be actively working to dismantle it.

According to Article III of the WTO Agreement, the WTO shall 'facilitate the implementation, administration and operation, and further the objectives' of the covered agreements. It shall also 'provide a forum for negotiation among its members concerning their multilateral trade relations', administer the Dispute Settlement Understanding (DSU) and the Trade Policy Review Mechanism (TPRM) and strive for global economic policy coherence together with the International Monetary Fund and the World Bank. Beyond these codified aims, there is no shared understanding among the academic or professional trade policy community about the political purposes and goals of the WTO.

In terms of governing commercial exchanges, trade liberalization and the provision of market access between countries are seen by many scholars as the WTO's primary purpose (Jackson, 2002; Bhagwati, 2008). Others challenge the view of trade liberalization as an end in itself and see the distribution of trade gains and benefits for smaller members as the WTO's overarching objective (Egger and Olarreaga, 2014; Wilkinson et al., 2014). In political terms, the WTO conditions not only the global, but also the domestic political environments in which trade policy decisions are made. Some see the WTO's purpose as helping governments to resist domestic political economy pressures (Maggi and Rodríguez-Clare, 1998). Others reject the depolitizing logic and want the WTO to provide a forum where 'political actors cohere and engage in debate' (Kapoor, 2004: 525). Building on Robert Keohane's (2001) prerequisites for successful social institutions, John Jackson highlights accountability and the closeness of governments to its constituents, 'participation that is open to all', and 'persuasion in a thoughtful and non-polemic way' as important ideals of international cooperation towards which the WTO ought to strive (Jackson, 2002: 105).

When asked to explain the purpose of the WTO, interviewees provided varied responses that mirror the contestation in the literature. The semi-structured, open-ended nature of the interviews gave participants influence over the course of the conversation. In 33 out of 105 interviewees, the question of the WTO's purpose was either not asked, or participants deviated from the question in their answers. This number was excluded from the calculations presented below. Every participant typically provided several answers, which were individually counted per country and per type of actor. To allow comparison across countries and types of actors, each column in the tables below indicates the distribution of purposes/functions per country (Figures 1 and 3 ) or per type of actor (Figures 2 and 4).

Figure 1 shows the political purpose that the WTO holds according to interviewees in five thematic sub-categories, presented by country. Figure 2 arranges the data by type of actor. Thematic sub-categories constitute archetypes of political purposes, rather than the exact wording used in interviews. The sub-category 'trade liberalization' includes direct references to trade liberalization, the provision 
Figure 1. WTO purposes by member (in percent and excluding international interviewees)

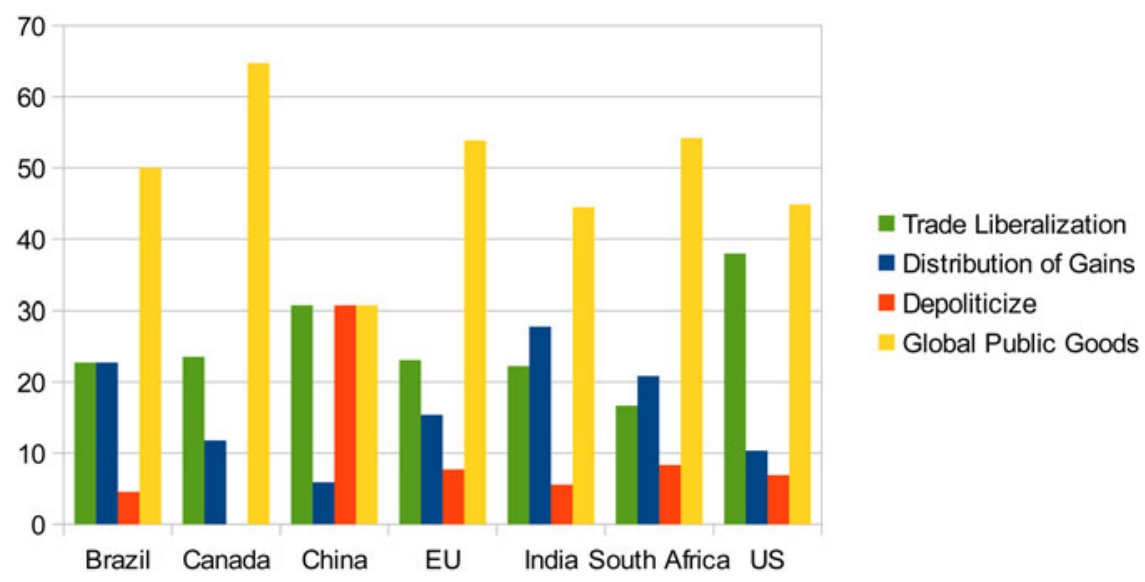

Figure 2. WTO purpose by type of actor (in percent and including international interviewees)

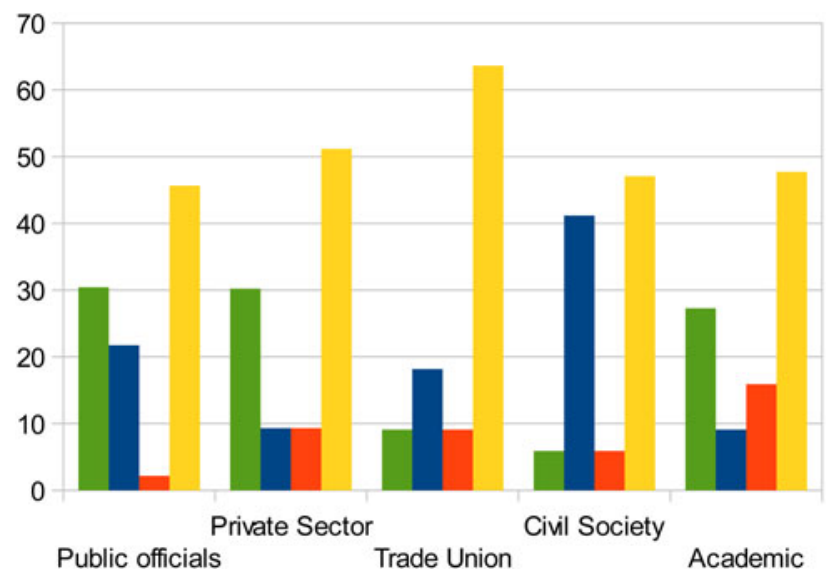

- Trade Liberalization

- Distribution of Gains

Depoliticize

Global Public Goods

of market access, and open markets. The sub-category 'distribution of gains' from trade also comprises the provision of benefits to all members and contributions to development. 'Depoliticizing' trade policy-making captures the view that international trade rules condition and/or discipline domestic policy-making. All answers highlighting transparency and dialogue, dispute settlement, and negotiating multilateral rules are subsumed under the provision of 'global public goods'. Global public goods are non-rivalrous in consumption and non-excludable, and their benefits apply universally (Kaul et al., 1999). 
Figure 3. WTO functions by member (in percent and excluding international interviewees)

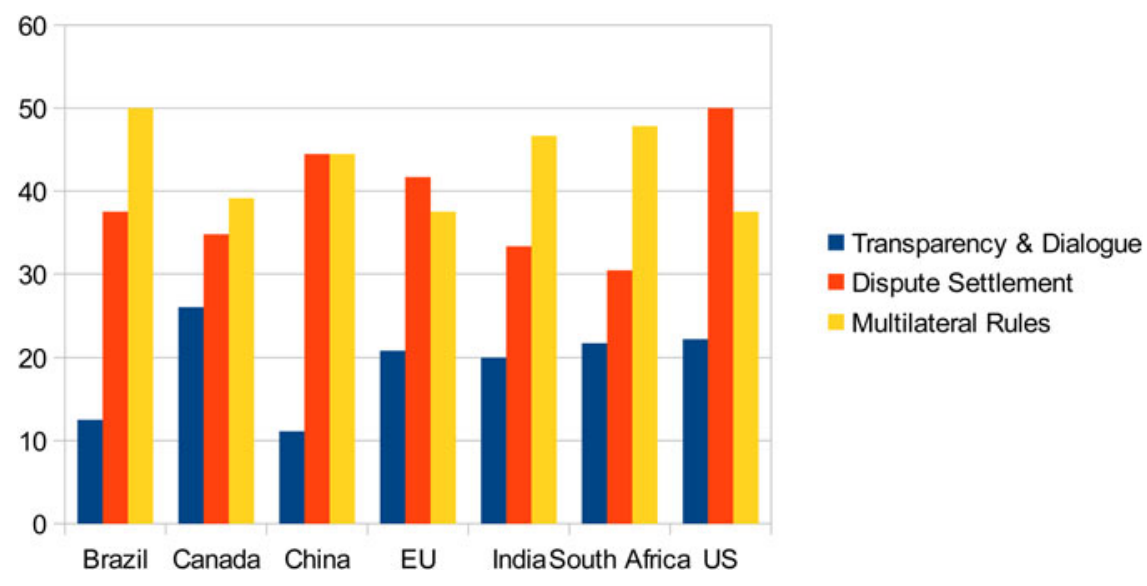

Figure 4. WTO functions by type of actor (in percent and including international interviewees)

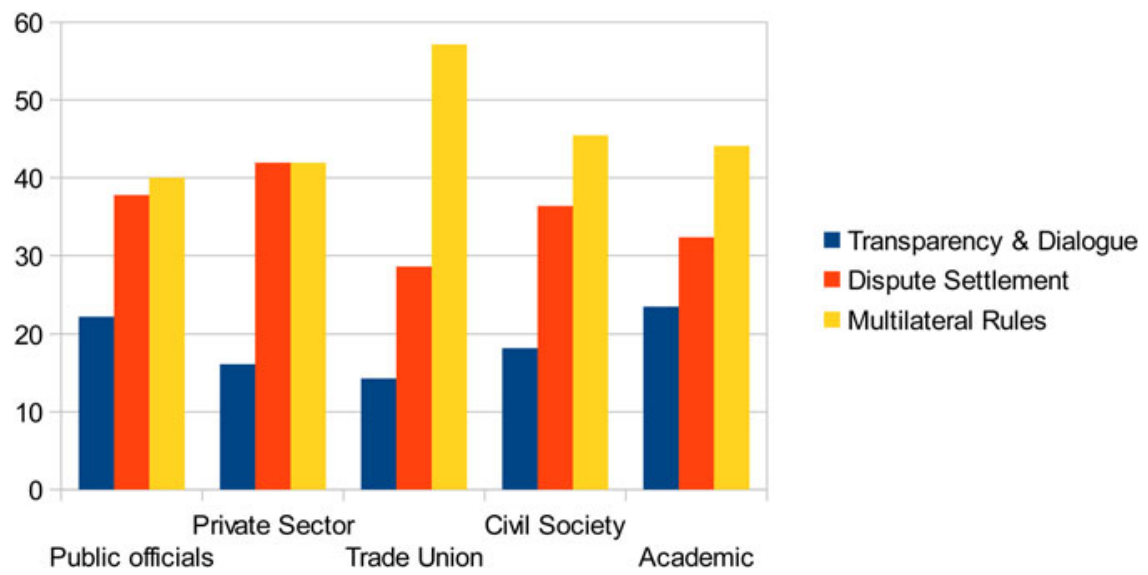

The sample indicates, as an Indian trade official argued in the interview, that what is seen as the WTO's purpose among practitioners 'depends on the country and the person'. Trade liberalization was overall cited more often than managing the distribution of trade gains in Canada, China, the EU, and the US, as well as among public officials, the private sector, and academic experts. In Brazil, India, South Africa, and among trade unionists and civil society actors, distributing trade gains was considered on the whole more important than trade liberalization per se. Depoliticizing trade policy-making was almost exclusively a concern for 
academic circles, with the exception of China. In all countries and among all actors, the provision of global public goods was more frequently evoked than the next most popular purposes, trade liberalization and the distribution of trade gains. Irrespective of diverging views of how the WTO fares in delivering these global public goods, practitioners agreed that a multilateral institution was essential for global trade governance.

Figures 3 and 4 open up the sub-category of global public goods by showing the frequency with which each of the three functions, transparency and dialogue, dispute settlement, and multilateral rules, was highlighted in the interviews.

In Brazil, Canada, India, South Africa, and among public officials, trade unionists, civil society representatives, and academics, the provision of multilateral rules was the most frequently raised function that the WTO carries in international trade cooperation. In the EU and in the US, dispute settlement was more often cited as a key WTO function than providing multilateral rules. In China and among private sector representatives, both functions appeared to be seen as equally important. Transparency and dialogue were the least frequently evoked functions, but had the highest standing in Canada, the EU, South Africa, and the US, and among public officials and academic experts.

Simplicity of rules and balancing of power relations in international trade were most frequently cited as important features of good global trade governance that the WTO could in principle help work towards. An EU trade official for example asserted that 'even if we can project our interests through bilateral rapport in trade and investment relations with third countries, we do gain a lot from the protection of an enforceable rules-based system ... rather than simply having recourse constantly to the politics of leverage. Because if you don't have the WTO, the only thing you have left is the politics of leverage.' Similarly, a Brazilian trade official explained that 'the WTO gives the basic reference ... for the behavior that is acceptable for the different countries. If the countries did not have that, they would to a much greater extent use their purchasing power to influence and infuse other countries to adopt specific behaviors, and even with the WTO that happens sometimes.'

Private sector representatives also shared the view that what a South African business representative called 'the law of the jungle' was bad for global trade relations. A Canadian business representative argued that the WTO 'is not actually free trade, it's managed trade. But that's better than one-off regimes or regimes that favor the more geopolitically or militarily powerful countries.' A US business representative confirmed: 'it's all about the rules, there's gotta be rules that countries follow on trade matters' and added that in this respect, 'the WTO is critical. Having a strong WTO is of utmost importance not just to the US business community but to the global business community.' A European business representative added: 'our interest is always first pursuing the multilateral trade agenda, cause it's just easier for business'.

Labor and civil society organizations in principle agreed, in the words of a US trade unionist, that 'the goal of having a single unified set of international trade 
rules is important'. At the same time, interviewees acknowledged diverging perspectives on the WTO within their groups. A Brazilian civil society representative pointed out that 'some of us think the WTO should shut down, others think that it is better having a multilateral space than leaving the world trade system without a system and just leave it for FTAs and the bilateral correlation of forces'. A European trade unionist reported that 'the more left trade unions are very skeptical, and the others are much more pragmatic and say we need harmonization worldwide and multilateralism should be the approach we aim at'.

Given the importance that interviewees attached to the three governance functions, the following sections examine what the WTO's thick institutionalism contributes to the provision of each function. Each section asks how the functions can be expected to evolve during the PTA era, and how the thin institutionalism of the PTA network may affect international trade cooperation more broadly.

\section{Transparency and dialogue}

The WTO's thick institutionalism facilitates transparency and dialogue in global trade governance through several formal and informal mechanisms. While the literature focuses on the role of transparency in trade governance, interviewees showed concerns about how human and financial resource diversion to PTAs affects the quality of dialogue among them. This section suggests that there is a risk that information gaps rise and levels of trust and familiarity among members of the global trade policy community drop as political actors focus their capacities on institutionally thin, poly-centric PTA negotiations. In addition to members' notification obligations under certain WTO agreements, the WTO's TPRM serves to periodically assess trade policy measures taken by individual WTO members (for a historical perspective, see Mah, 1997). Trade Policy Reviews (TPR) analyze trade policies and practices as well as the economic and trade environment of every WTO member every two, four, or six years, depending on a member's trade share. The interim period can be longer for Least Developed Countries (LDC). Reports are compiled by the WTO Secretariat's Trade Policy Review Division, which is the third largest division in the Secretariat (WTO, 2016b). Members discuss findings in the WTO's TPRB (WTO, 2016c). By late 2013, the WTO had conducted 384 TPRs providing transparency and mutual understanding of domestic trade policy trends and measures of 147 of then-159 members (WTO, 2013). All WTO members benefit from the information compiled through the WTO's TPRM, as in its absence, each member, as well as other state and non-state actors with a stake in world trade politics, would have to monitor each state's policies individually. Because small trading nations and developing countries in particular often lack the relevant information, and the resources to compile it, TPR is seen as one instrument that corrects existing power imbalances in the global trading system (Chaisse and Chakraborty, 2014). As Arunabha Ghosh points out, 'even as some developing countries have started to build domestic 
monitoring capacities, for most members the multilateral information system is still essential for getting credible and timely information' (Ghosh, 2010: 420). Because TPRs are public, they also improve information levels in the broader trade policy community (Keesing, 1998).

TPR does not operate in a political vacuum. Promoting compliance with internationally agreed trade rules by peer pressure and filling information gaps to enable countries to take matters up for dispute help to consolidate the trade regime and redress (some) information and capacity asymmetries among members. Yet, more powerful actors in the system are better placed to pursue their interests through the transparency and dialogue function. As Ghosh notes, 'economic analysis of trade policies could easily slide into the realm of economic prescription of "good" policies' (Ghosh, 2010: 439). The TPRB thus explicitly aims to maintain the neutrality of the WTO Secretariat during reviews. It also incorporates members' requests for improving the mechanism, ranging from identifying technical assistance needs of developing countries (WTO, 1999) through focusing on behindthe-border measures in goods and services (WTO, 2013), to improving efficiency, for example by using trade-relevant macroeconomic information from other international organizations (WTO, 1999), or by moving to electronic forms of documentation to reduce the cost of review for members (WTO, 2013).

In an era where global trade rules increasingly look like spaghetti bowls, TPRM becomes more, rather than less, important. This is particularly true for trade political actors that do not possess the human and financial resources to keep abreast of evolving domestic trade policies and bilateral relations across the world. Yet, even the TPRB mentions rising resource constraints as one area for concern in its latest appraisal of TPRM (WTO, 2013). Concerns about how PTA negotiations put a strain on human and financial resources were commonly raised in interviews. A European civil society representative explained: 'Following WTO negotiations was a full-time job, but one person could do it.' A European trade unionists testified: 'we are not able to follow hundreds of FTAs simultaneously, we don't have the resources'. Trade officials from core trading nations also indicated that in the PTA era, even powerful trade bureaucracies of the caliber of USTR, the European Commission's Directorate-General for Trade, or China's Ministry of Commerce have downsized their internal units dealing with multilateral trade in order to free human and financial resources for preferential deals. Some interviewees expressed concern that, particularly with the steadily growing web of overlapping deals, this could lead to generalized ignorance and confusion about the structure and contours of the global trading system. A policy expert with a Brazilian think tank showed frustration in the interview over their perception that 'nobody has the slightest idea how the rules in the different agreements overlap and what is going on. Governments don't, many people are not familiar with these details.'

Interviewees argued that the problem of shifting resources towards the preferential realm also had implications for the quality of dialogue and exchange among 
political actors in the global trade system. Close contact and interaction through member states' representations to the WTO facilitates the formulation of trade policy at the international level and at home (Hoekman and Kostecki, 2001). According to interviewees, continuous, formal, and informal gatherings outside of the WTO's negotiating framework, also in and around other Geneva-based organizations working on trade and trade-related global policy issues - such as the United Nations Conference on Trade and Development, the International Trade Centre, and the World Intellectual Property Organization - constitute vital processes allowing them to exchange and deliberate on domestic trade policies, global economic events, and potential trade policy responses. As a Canadian trade official remarked in the interview: 'in the WTO, by the time it reaches any formal meeting, it's cooked or it isn't'.

There are stark differences in staff numbers among members' WTO missions. While big trading nations such as the US, the EU, and China have separate, wellstaffed WTO missions in addition to their UN missions and diplomatic representations to Switzerland, the LDC missions had on average 4.1 staff members in 2008 , with many of them simultaneously representing their country in all international organizations in Geneva as well as taking on consular functions (DiCaprio and Trommer, 2010). Interviewees further suggested that the quality of representation in Geneva not only depends on numbers, but also on the quality of staff. The Canadian trade official argued that in the WTO, 'the role of nations ebbs and flows based on the representatives'. Therefore, 'what countries find is if they don't want to make the investment of putting in somebody really good in Geneva, they have less of a role in the WTO'.

Although asymmetry exists among countries and political actors in their level and quality of representation to the multilateral system, the PTA network lacks a geographical epicenter in which the entire global trade policy community physically meets on daily basis. Thus, dialogue on global trade may suffer as political actors turn their scarce resources to preferential negotiations. There is a further risk in the PTA era that countries stop sending their best and brightest to Geneva. The quality of dialogue and exchange among the global trade policy communities could subsequently drop, as brains and money drain to the preferential realm. A Canadian academic expert questioned in the interview 'whether countries will keep sending good ambassadors and good staff to Geneva.' This was important, the interviewee explained, 'because ultimately it's people. If the people aren't there the thing will fall apart.'

In terms of transparency and dialogue, fragmentation and thin institutionalism risk exacerbating power asymmetries and causing cooperation problems due to growing issue uncertainty, and resource-constrained information and dialogue. This may produce negative effects on the overall quality of global trade governance, because information and exchange of views are vital in all aspects of international cooperation, whether in agenda-setting, negotiation, implementation, monitoring, or enforcement of rules. While the problem affects all partners to international 
trade cooperation, it is likely to affect marginal trade political actors and small trading nations more adversely, as they face bigger human and financial resource constraints making it harder to summon the institutional capacity required to make sense of, and continue to participate in, the fragmented governance architecture for global trade. The next section examines dispute settlement in this context.

\section{Dispute settlement}

The WTO's political organs and the Secretariat provide the institutional infrastructure for resolving international trade disputes, including administrative and legal support. This section suggests that institutional support is crucial for access to legal recourse, continuity of legal reasoning, and fairness. In the absence of institutional structures, the adjudication of international trade disputes under PTA dispute settlement may return to a more diplomatic, rather than judicial format. Small trading nations in particular face resource constraints and systemic exclusion, and can be expected to participate less in PTA dispute settlement than they do under the WTO.

Since 1995, the WTO has received over 500 cases and two-thirds of members have participated in WTO dispute settlement. As testified by the high number of disputes filed in Geneva (WTO, 2015), members' enthusiasm for WTO dispute settlement appears unbroken. Although states negotiate dispute settlement provisions in PTAs, they do not use them (Chase et al., 2013).

The literature identifies several factors to account for this phenomenon. Where a dispute among two nations relates to matters covered under the WTO Agreements, Article 23 of the DSU mandates adjudication under the WTO Dispute Settlement Mechanism (DSM). States may prefer multilateral adjudication where disputes have multilateral implications. Further reasons for choosing WTO over PTA DSM may range from 'the cost-benefit analysis which is carried out in terms of economic as well as political costs, to the efficacy of a specific DSM' and 'the legitimacy of a mechanism' (Marceau, 2015: 13). Analyzing dispute settlement exclusion clauses and special procedures across 258 active PTAs notified to the WTO by September 2014, Marc Froese (2016) finds that PTAs typically exclude areas such as competition policy and labor and environmental standards from their dispute settlement clauses and revert back to the multilateral system in behind-the-border areas, notable Sanitary and Phytosanitary Measures (SPS), Technical Barriers to Trade (TBT), and trade defense. Therefore, PTA 'dispute settlement ... does not deepen the juridical reach of trade disciplines as much as might first be surmised' (Froese, 2016, forthcoming).

Furthermore, the WTO provides the institutional and procedural support that is essential for the rule of law character of its DSM. The WTO Secretariat's Legal Affairs Division, the Appellate Body Secretariat, and the WTO's organs such as the Dispute Settlement Body (DSB), the Director-General, and the Appellate Body all engage in essential legal background work and their institutionalized 
roles in dispute settlement limit members' ability to block the hearing of a dispute. WTO dispute settlement proceeds in four stages: consultation, adjudication, appeal, and sanctions. According to Article 27 DSU, the WTO Secretariat assists members in dispute settlement proceedings at their request, including proposing nominations for panelists. If the parties to a dispute cannot agree on the composition of the panel, which is often the case, either party may ask the WTO Director-General to determine the composition of the panel, again undermining members' ability to prevent a dispute from being adjudicated (WTO, 2016d).

Once a panel is established, the WTO Secretariat is responsible for the administrative and logistical aspects of running the dispute. It advises panels on legal and procedural points, thus providing institutional memory, continuity, and consistency between panels. It conducts special training courses on dispute settlement and gives legal advice and assistance to developing countries (WTO, 2016d). By making panel reports subject to appeal in front of a standing body, the DSU 'intended to bring "the rule of law" into the international trading system and to create stability, predictability, and fairness in international trade' (Matsushita, 2012: 511-512). A selecting committee established by the DSB appoints Appellate Body members for a period of four years that is once renewable. The DSB serves to oversee members' implementation of dispute settlement reports. It is also the political organ that authorizes the suspension of obligations, should a party not comply with the recommendations of a dispute settlement report (WTO, 2016d).

Observers are divided on whether multilateral dispute settlement is more advantageous for small or for big traders. Some argue that WTO DSM brings more benefits to developing country members than to members who have never invoked the status, 'since the former do not always possess the necessary bargaining power to force the latter to withdraw ... WTO-incompatible policies' (Chaisse and Chakraborty, 2014: 157). Others point out that in practice, wealthy WTO members and big traders are better placed at all stages of dispute settlement to assert their rights in the multilateral trade regime. Scholars have identified economic diversification and market size (Sattler and Bernauer, 2011), legal capacity (Kim, 2008), ability to impose sanctions (Bown and Pauwelyn, 2010), and balancing trade with other foreign policy priorities (Elsig and Stucki, 2012) as reasons for the asymmetry.

Imperfect as the rules-based character of the multilateral system may be, a US business representative explained that the dispute settlement function is more effective than any of the other mechanisms that we've devised under bilateral regional agreements'. An Indian academic expert testified that 'the WTO dispute settlement has its faults, but the arbitration that many of the RTAs go through is appalling'. Peter Drahos argues that power asymmetries further benefit the larger partner in PTA dispute settlement even more than in WTO dispute settlement (Drahos, 2007). Dispute settlement clauses in PTAs only provide legal recourse for contracting parties, although their rules produce effects on trade flows of 
Figure 5. WTO dispute settlement statistics 1996-2015

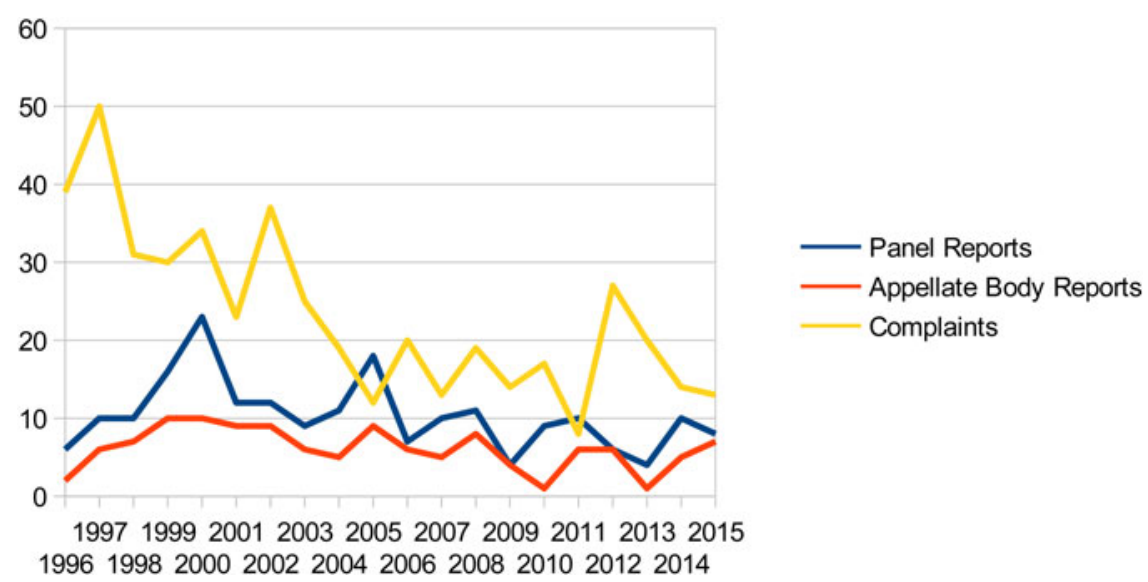

Source: worldtradelaw.net

non-members. For these reasons, the PTA network cannot provide the same level of legal certainty and stability as the multilateral DSM.

The data suggest that the PTA realm's thin institutionalism further undermines the rule of law character of dispute settlement. Although PTA dispute settlement clauses are often modeled on the WTO DSM, one interviewee associated with an international organization pointed out that they generally do not create the institutional infrastructure to support the day-to-day operation of trade courts. Because the institutional support described above is not available under PTA dispute settlement, access to dispute settlement and continuity of legal reasoning cannot be guaranteed to the same degree. A Chinese academic pointed out in the interview that PTA dispute settlement 'cannot compare [to WTO DSM], they do not have privileges like the DSB'. A European civil society representative asserted that 'dispute settlement at the WTO ... offer[s] better protection for the small developing countries'.

Similarly to transparency, the WTO's own resource constraints limit dispute settlement. Figure 5 shows the number of panel and Appellate Body reports circulated, and the number of disputes filed, per year from 1996 to 2015.

The WTO has never delivered more than ten Appellate Body reports in any given year. Panel reports peaked at 23 in 2000, but over the 1996-2015 period, the average was approximately ten reports per year. In his 2015 remarks to the Graduate Institute in Geneva, Ambassador Ronald Saborío Soto, Chairman of the DSB, raised 'present workload challenges' as one issue in WTO DSM and explained that 'members' increasing reliance on WTO dispute settlement has created pressures on the capacity of the system to meet the demands being placed on it' (WTO, 2016e). Director-General Roberto Azevêdo warned in 2014 that with regard to dispute settlement, 'we are in a situation where the demand is 
severely testing our capacity'. Due to a rise in number and complexity of disputes, and the Appellate Body's institutional limitations, which only enable it to hear up to three cases in parallel, Azevêdo reported 'an insurmountable bottleneck at the Appellate Body stage' of disputes (WTO, 2014). The interviewee participating in the study further pointed out that strains on financial and human resources resulting from a higher number of cases are one important reason why disputes take longer to resolve on average in the WTO.

In terms of dispute settlement, fragmentation and thin institutionalism risk jeopardizing the rules-based character of the global trade governance architecture. Capacity asymmetries in dispute settlement, systemic exclusions of trading nations and of trade topics resulting from poly-centric, institutionally thin PTA dispute settlement, and resource-constrained adjudication hamper the effectiveness, accessibility, and reliability of legal recourse in international trade relations. The developments can be expected to affect small traders more adversely than large trading nations. They may ring in a return to resolving trade disputes through power politics, rather than, however imperfect, third-party adjudication through the WTO.

Despite concerns, participants were on the whole optimistic about the WTO's transparency and dialogue and adjudication functions. As a Chinese academic remarked, 'the trade policy review mechanism and dispute settlement are running well. The problem is with negotiations'. The next section examines the third function that the WTO provides in global trade governance.

\section{Multilateral rules}

Multilateral negotiations help in addressing power imbalance in international trade talks by their inclusive character and the institutional support that the WTO provides. Most interviewees in principle preferred the transparency, enforceability, and simplicity of the unified WTO rule book to the fragmentation of the PTA network. Yet, interviewees speculated that the WTO's strong DSM may be one element that has made the conclusion of multilateral negotiations more difficult. This section argues that PTAs may remain the preferred negotiating channel of powerful traders for some time to come, because thin institutionalism favors those with the resources and economic and political clout to pursue their interests in a watered-down rules-based system.

Unlike other international economic organizations, the WTO makes decisions by consensus on a one-country one-vote basis. Although its future as a negotiating principle is currently uncertain, the single undertaking rule, whereby 'nothing is agreed until everything is agreed', in principle allows issue linkages and the striking of a grand bargain among all members. A European civil society representative voiced a widely acknowledged fact of trade governance when pointing out in the interview that inclusive decision-making in the WTO 'of course makes negotiations more difficult, but that's of course how it goes'. 
Poly-centric PTA negotiations produce obstacles for effective political participation by small countries. As an Indian private sector representative highlighted, 'the fundamental problem [with shifting to PTA negotiations] is where the small countries will go'. Small traders risk being entirely excluded from PTAs, or, where they are included, areas of interest to them might be excluded, and they lose their ability to bargain collectively. In addition, the WTO Secretariat provides administrative and technical support in negotiations that is particularly relevant for smaller members. The WTO Secretariat's Languages, Documentation and Information Management Division, the Administration and General Services Division, the Information Technology Solutions Division, and the Economic Research and Statistics Division directly support the WTO's various councils and negotiating committees (WTO, 2016b).

The Institute for Training and Technical Cooperation assists beneficiary members of trade-related technical assistance with their integration into the trading system. This includes enhancing their institutional and human capacity in trade, participation in in negotiations and exercising their membership rights. While providing invaluable support work for trade negotiations, the Secretariat and the Director-General have been criticized for politically biased interventions in negotiating processes (Jawara and Kwa, 2004). Informal talks that are so central to negotiation outcomes in the WTO's political culture have excluded the vast majority of members (Schott and Watal, 2000).

Most interviewees shared the prevalent view in the literature that 'the WTO is unlikely to be a major forum for negotiating new policy disciplines in the next few years' (Hoekman, 2014: 243). At the same time, interviewees saw the multilateral negotiating tract as superior to preferential deals due to its 'one-stop-shop' character for trade governance. A European private sector representative explained the WTO's enduring allure in the following manner: 'for the countries taking part, it's the inclusivity. But for business using global trade rules, it's the uniformity of the rules and the simplicity of the system.' An affiliate from a Brazilian think tank explained, 'for a country like Brazil the WTO is very important because Brazil has a very diversified trade ... The WTO is the only place where we can negotiate trade rules.'

A number of interviewees pointed out that continuing WTO committee work was important in terms of developing new rules, yet often neglected in debates about multilateral trade governance. A Canadian trade official explained: 'Nobody talks about the TBT or the SPS committee right? What we don't hear about is that the SPS committee meets twice or maybe three times a year, we have global agricultural regulators coming together, and first of all they learn from each other, but second of all, even if they have difficulties with what one or the other are doing, they talk it out, figure out better ways of doing it. And so in essence those conversations are setting global norms. Totally unheralded, but it provides that mechanism and it does it under this umbrella of what we have of global rules.' 
Many interviewees expressed concern about the continuing fragmentation of global trade rules. A Chinese academic emphasized that 'the WTO is the right way for setting international rules and regulations and not to have fragmentation of the rules'. Fragmentation of rules was seen as problematic, in the words of a Brazilian trade official, because 'you would divide the world between those who follow US rules, those who follow EU rules, and so on'. As Bernard Hoekman points out, 'rules of origin, regulatory convergence and mutual recognition among mega PTA members may create incentives for companies to locate in a bloc, or to source from firms located within a bloc' (Hoekman, 2014: 243). As a result, PTAs may entrench commercial fragmentation by the fragmented preference structure they create. Because PTAs create regional blocs, one Canadian private sector representative explained that 'all business without much exception thinks the WTO is almost a first, best solution ... We want to have global supply chains and I want to stop spending so much money trying to comply with the different rules of different bilaterals or frankly, ending up in situations where I've bypassed them entirely because they don't mesh well with my business model.'

Some scholars argue that this effect will eventually produce the political pressures that are necessary to bring countries back to the multilateral negotiating table (Blanchard, 2015). If, how, and whose PTA rules can be multilateralized will ultimately depend on preferential negotiating outcomes and on the global political economy background against which multilateralization will be attempted. Many interviewees saw the global economy as undergoing a period of changing underlying power relations and argued that the shape of the future trade regime will become clearer once the adjustments have taken place. Others speculated that the failure of preferential talks could provide the political momentum to bring countries back to the multilateral table.

Interviewees were split in their assessment of how current negotiating initiatives will affect future possibilities of multilateralizing outcomes. Some interviewees pointed to historical precedents of plurilateral advances to argue that this approach could reinvigorate multilateralism. A US trade official asserted: 'the road ahead is plurilaterals within the WTO. They are not the opposite of the WTO and multilateralism. Look at the Tokyo Round, that round was concluded purely on plurilateral results.' Other interviewees feared that plurilateral negotiations would undermine core multilateral principles of inclusiveness, non-discrimination, and transparency. An Indian business representative expressed the view that if the trend towards plurilaterals emerges any stronger, that will only further dilute or downgrade the hands of WTO or multilateralism'. In addition, plurilateral negotiations were seen as preventing regular institutionalized exchanges among all WTO members. A South African trade official pointed out that 'the WTO has been a very important source of empowerment and social learning. For many countries with limited capacity, by being involved in the negotiations, they have been able to learn about issues and build their capacity. This is a case against plurilateral negotiations, countries have this expectation to be involved and included.' 
Some interviewees reported that the enforceability of multilateral rules through the WTO's strong DSM has made negotiators cautious about the language used in trade deals. An affiliate of a US think tank argued that partly as a result of countries' experiences with enforceable WTO dispute settlement, 'most of the negotiators are lawyers and are parsing the words very, very carefully'. This in turn precludes the use of creative ambiguity in multilateral trade talks, which has been a tried and tested negotiating technique in previous rounds. As Marc Froese (2016) finds, many contentious areas in PTAs are in effect excluded from dispute settlement. PTAs could constitute the privileged forum for trade negotiations for some time to come, precisely because they offer the possibility of excluding areas from dispute settlement, and, as the previous section showed, their dispute settlement mechanisms are more diplomatic in character. When it comes to dispute settlement provisions, thin institutionalism and its implications for political flexibility could be one element that makes PTAs attractive from the perspective of negotiators.

Legal scholars have long argued that form and content are inextricably linked in political interaction at the WTO, partly because law and politics cannot be neatly separated in international interaction (Cottier, 2007). Joost Pauwelyn (2005) asserts that the WTO's strong rule enforcement capacities rely on strong rights of political participation in decision-making in order to retain long-term legitimacy in the eyes of all members. The data suggest that strong dispute settlement provisions could have dampening effects on the ability to reach new agreements in international trade, and in international law more broadly, although this finding requires further analytical and theoretical attention. The final section summarizes this article's findings and highlights avenues for future research.

\section{Conclusion}

The empirical study shows that the 105 trade policy practitioners interviewed from seven core WTO members and several international organizations continue to place high value on trade multilateralism. Across all types of actors and trade political constituencies, interviewees saw a clear need for transparency and dialogue, adjudication of trade disputes, and unified rules in global trade governance. As a quasi-universal one-stop-shop for these functions, a multilateral body like the WTO remains the ideal in world trade politics, even in the era of preferential trade diplomacy. The finding contradicts assumptions that core constituencies have lost interest in trade multilateralism and helps to draw a more subtle picture of how the institutional architecture for global trade governance is evolving.

Institutional rules in principle empower all members to access the WTO's governance functions. In practice, the procedural equality posited by the WTO legal and institutional regime exists alongside asymmetrical power relations among members. Various factors, including economic weight and technical capacity, remain essential for exercising rights in the WTO political context. Drawing on 
the practical insights of trade professionals, this article highlights that institutional support infrastructures play important roles in redressing (some of) the imbalance. The lack of concrete and tangible institutional infrastructures in the context of the ever-rising numbers of bilateral policy and arbitration venues characterizes the PTA network. Navigating the network therefore requires high human and financial resources from all actors in global trade governance. By its patchwork nature, it can be expected to disadvantage not only those who are excluded from PTAs, but also those who cannot readily summon the resources to pursue their policy goals in the context of thin institutionalism.

While the global trading system can theoretically operate with a multilateral baseline on which PTAs build, this article suggests that limitations to financial and human resources across all trade policy communities mean that one avenue is in practice pursued at the expense of another. The multiplication of trade policy forums and thin institutionalism compromise the rules-based nature of the global trade governance architecture in several respects. The ability of the global trade system to deliver transparent, enforceable, and simple global trade rules, and the overall quality of international trade cooperation all suffer, as the global trade governance architecture is redrawn in favor of more power-based modes of governance in the PTA era. While thin institutionalism has implications for all trade political actors, it can be expected to disproportionately affect small traders, for whom the WTO governance functions constitute a global public good that is not replaced by the PTA network.

Theoretically, this article provides one detailed example of how the proliferation of international institutions can lead global governance back towards more powerbased forms of international interaction. The differentiation between thick and thin institutions proved analytically useful in explaining why trade political actors continue engaging with both the multilateral system and the PTA network, a fact of trade political life that goes against the view that trade governance is experiencing a simple decline of multilateralism. Through thick institutionalism, the WTO provides many governance functions that trade policy professionals see as essential for the conduct of international trade relations. The PTA network not only allows negotiating new rules while the negotiating function of the WTO is blocked, but its thin institutionalism also re-introduces more flexibility in terms of inclusion of policy areas and compliance. At the same time, one member's increased flexibility is another member's erosion of legal certainty. This is particularly problematic for those in the global trade policy community who do not have the resources to ensure their concerns are addressed across the poly-centric policy venues of the PTA network.

This article posits thin institutionalism as one hypothetical outcome of PTA proliferation developed on the basis of observations in the trade governance, international relations, and European public policy literatures, and the insights provided in interviews. More literature is required to investigate its concrete iterations and impacts on all areas of international trade cooperation and global trade 
governance. The study allows identifying a number of pertinent questions with regard to the three governance functions that the WTO provides in world trade politics. Focusing on the institutional infrastructure of international trade cooperation allows investigating changes in the effectiveness of transparency and dialogue among the international trade policy community in the PTA era over time. Research may also focus on how institutional limitations hinder PTA dispute settlement, and connect strong dispute settlement back to the negotiating problems in the multilateral forum. Overall, law and politics remain inseparable in international economic life and need to be further theorized from a holistic standpoint. The same is true for the PTA realm and WTO-based international trade cooperation, which in the minds of trade practitioners remain part and parcel of the one world trade system, however fragmented it may become in economic, legal, and political terms.

\section{References}

Aggarwal, V. and S. Evenett (2013), 'A Fragmenting Global Economy: A Weakened WTO, Mega-FTAs, and Murky Protectionism', Swiss Political Science Review, 19: 550-557.

Alter, K. and S. Meunier (2009), 'The Politics of International Regime Complexity', Perspectives on Politics, 7: 13-24.

Baldwin, R. and E. Seghezza (2010), ‘Are Trade Blocs Building or Stumbling Blocs?', Journal of Economic Integration, 25: 276-297.

Bhagwati, J. (2008), Termites in the Trading System: How Preferential Agreements Undermine Free Trade, Oxford: Oxford University Press.

Biermann, F., P. Pattberg, H. van Asselt, and F. Zelli (2009), 'The Fragmentation of Global Governance Architectures: A Framework for Analysis', Global Environmental Politics, 9: 14-40.

Blanchard, E. (2015), 'A Shifting Mandate: International Ownership, Global Fragmentation, and a Case for Deeper Integration under the WTO', World Trade Review, 14: 87-99.

Bown, C. and J. Pauwelyn (2010), The Law, Economics and Politics of Retaliation in WTO Dispute Settlement, Cambridge: Cambridge University Press.

Capling, A. and P. Low (2010), Negotiating Preferentially or Multilaterally? Governments, Non-State Actors and Trade Policy-Making, Cambridge: Cambridge University Press, and Geneva WTO.

Capling, A. and J. Ravenhill (2011), 'Multilateralising Regionalism: What Role for the Trans-PacificPartnership Agreement?', The Pacific Review, 24: 553-575.

Chaisse, J. and D. Chakraborty (2014), 'Implementing WTO Rules through Negotiations and Sanctions: The Role of Trade Policy Review Mechanism and Dispute Settlement System', Journal of International Law, 28: 153-185.

Chase, C., A. Yanovich, J.-A. Crawford, and P. Ugaz (2013), Mapping Dispute Settlement Mechanisms in Regional Trade Agreements: Innovative of Variations on a Theme? WTO Economic and Statistics Division Staff Working Paper ERSD-2013-07, Geneva: WTO.

Cottier, T. (2007), 'Preparing for Structural Reform in the WTO', Journal for International Economic Law, 10: 497-508.

Davis, C. (2009), 'Overlapping Institutions in Trade Policy', Perspectives on Politics, 7: 25-31.

DiCaprio, A. and S. Trommer (2010), 'Bilateral Graduation: The Impact of EPAs on LDC Trade Space', Journal of Development Studies, 46: 1607-1627.

Drahos, P. (2007), 'Weaving Webs of Influence: The United States, Free Trade Agreements and Dispute Settlement', Journal of World Trade, 41: 191-210.

Drezner, D. (2013), 'The Tragedy of the Global Institutional Commons', in M. Finnemore and J. Goldstein (eds.), Back to Basics: State Power in a Contemporary World, Oxford: Oxford University Press, pp. 280-310. 
Egger, P. and M. Olarreaga (2014), 'Introduction to the Special Issue on the Political Economy of Multilateral Trade Negotiations', Review of International Organizations, 9: 135-142.

Elsig, M. and P. Stucki (2012), 'Low-income Developing Countries and WTO Litigation: Why Wake Up a Sleeping Dog?', Review of International Political Economy, 19: 292-316.

Evenett, S. (2014), 'The Doha Round Impasse: A Graphical View', Review of International Organizations, 9: $143-162$.

Froese, M. (2016), 'Mapping the Scope of Dispute Settlement in Regional Trade Agreements: Implications for the Multilateral Governance of Trade', World Trade Review, 15: 563-585.

Ghosh, A. (2010), 'Developing Countries in the WTO Trade Policy Review Mechanism', World Trade Review, 9: 419-455.

Hoekman, B. (2014), 'Sustaining Multilateral Trade Cooperation in a Multipolar World Economy', Review of International Organizations, 9: 241-260.

Hoekman, B. and M. Kostecki (2001), The Political Economy of the World Trading System: WTO and Beyond, Oxford: Oxford University Press.

Jackson, J. (2002), 'Perceptions about the WTO Trade Institutions', World Trade Review, 1: 101-114.

Jawara, F. and A. Kwa (2004), Behind the Scenes at the WTO: The Real World of International Trade Negotiations, London: Zed Books.

Kapoor, I. (2004), 'Deliberative Democracy and the WTO', Review of International Political Economy, 11: $522-541$.

Kaul, I., I. Grunberg, and M. Stern (1999), Global Public Goods: International Cooperation in the 21st Century, New York: United Nations Development Programme and Oxford University Press.

Keesing, D. (1998), Improving Trade Policy Reviews in the World Trade Organization, Washington, DC: Institute for International Economics.

Keohane, R. (2001), 'Governance in a Partially Globalized World', The American Political Science Review, 95: 1-13.

Kim, M. (2008), 'Costly Procedures: Divergent Effects of Legalization in the GATT/WTO Dispute Settlement Procedures', International Studies Quarterly, 52: 657-686.

Maggi, G. and A. Rodríguez-Clare (1998), 'The Value of Trade Agreements in the Presence of Political Pressures', Journal of Political Economy, 106: 574-601.

Mah, J. (1997), 'Reflections on the Trade Policy Review Mechanism in the World Trade Organization', Journal of World Trade, 31: 49-56.

Marceau, G. (2015), 'The Primacy of the World Trade Organization Dispute Settlement System', Questions of International Law, 23: 3-13.

Matsushita, M. (2012), 'The Dispute Settlement Mechanism at the WTO: The Appellate BodyAssessment and Problems', in A. Narlikar, M. Daunton, and R. Stern (eds.), The Oxford Handbook on the World Trade Organization, Oxford: Oxford University Press, pp. 507-534.

Mercurio, B. (2009), 'Reflections on the WTO and the Prospects for its Future', Melbourne Journal of International Law, 10: 49-57.

Muzaka, V. and M. Bishop (2015), 'Doha Stalemate: The End of Trade Multilateralism?', Review of International Studies, 41: 383-406.

Paraskevopoulos, C. (2002), 'New Institutionalism and EU Regional Policy: Multi-level Governance by “Thin” or “Thick” Institutions?', Current Politics and Economics of Europe, 11: 159-179.

Papa, M. (2015), 'Sustainable Global Governance? Reduce, Reuse, and Recycle Institutions', Global Environmental Politics, 15: 1-20.

Pauwelyn, J. (2005), 'The Sutherland Report: A Missed Opportunity for Genuine Debate on Trade, Globalization and Reforming the WTO', Journal of International Economic Law, 8: 329-346.

Sattler, T. and T. Bernauer (2011), 'Gravitation or Discrimination? Determinants of Litigation in the World Trade Organization', European Journal of Political Research, 50: 143-167.

Schott, J. and J. Watal (2000), 'Decision Making in the WTO', in J. Schott (ed.), The WTO after Seattle, Washington, DC: Institute for International Economics, pp. 283-291.

Trommer, S. (2014), Transformations in Trade Politics: Participatory Trade Politics in West Africa, London: Routledge. 
Wilkinson, R., E. Hannah, and J. Scott (2014), 'The WTO in Bali: What MC9 Means for the Doha Development Agenda and Why it Matters', Third World Quarterly, 35: 1032-1050.

WTO (1999), Appraisal of the Operation of the Trade Policy Review Mechanism, WT/MIN(99)/2, Ministerial Conference Seattle.

_ (2013), Fifth Appraisal of the Trade Policy Review Mechanism, WT/MIN(13)/, Ministerial Conference Bali.

_ (2014), 'Azevêdo says success of WTO Dispute Settlement brings urgent challenges', last modified 26 September, https://www.wto.org/english/news_e/spra_e/spra32_e.htm.

- (2015), 'Annex to Director-General's Statement at the DSB Meeting of 28 October 2015: Current Dispute Settlement Activity', last modified 28 October, https://www.wto.org/english/news_e/ news15_e/dsbannex_e.pdf.

_ (2016a), 'Regional Trade Agreements', https://www.wto.org/english/tratop_e/region_e/region_e.htm (accessed 15 November 2016).

_ (2016b), 'Overview of the WTO Secretariat', https://www.wto.org/english/thewto_e/secre_e/intro_e. htm (accessed 15 November 2016).

— (2016c), 'Trade Policy Reviews', https://www.wto.org/english/tratop_e/tpr_e/tpr_e.htm (accessed 15 November 2016).

_ (2016d), 'The Process: Stages in a Typical WTO Dispute Settlement Case', https:/www.wto.org/ english/tratop_e/dispu_e/disp_settlement_cbt_e/c6s2p1_e.htm (accessed 28 June).

(2016e), 'WTO Dispute Settlement Body - Developments in 2015', https://www.wto.org/english/ tratop_e/dispu_e/ronald_15_e.htm (accessed 1 July).

\title{
Appendix 1: Organizations participants were affiliated with at time of interview
}

\author{
Country \\ (Year of field work) Organizations \\ Brazil (2013) BRICS Policy Centre \\ CINDES - Centro de Estudos de Integração e Desenvolvimento \\ CNI - National Confederation of Industry \\ CSA - Confederación Sindical de Las Américas \\ DIEESE - Departamento Intersindical de Estatística Estudos Socioeconômicos \\ FASE - Federação de Órgãnos para Assistência Social e Educacional \\ FIESP - Federação des Indústrias de Estodo de São Paulo \\ Finance Ministry \\ Itamaraty \\ Ministry of Development \\ Pork Meat Association \\ Canada (2014) Canadian Chamber of Commerce \\ Canadian Council of Chief Executives \\ Centre for International Governance Innovation \\ Centre for Policy Alternatives \\ Department of Foreign Affairs, Trade and Development \\ North South Institute \\ Queens University \\ University of Ottawa \\ UNIFOR - Union for Canada
}


Appendix 1: (Cont.)

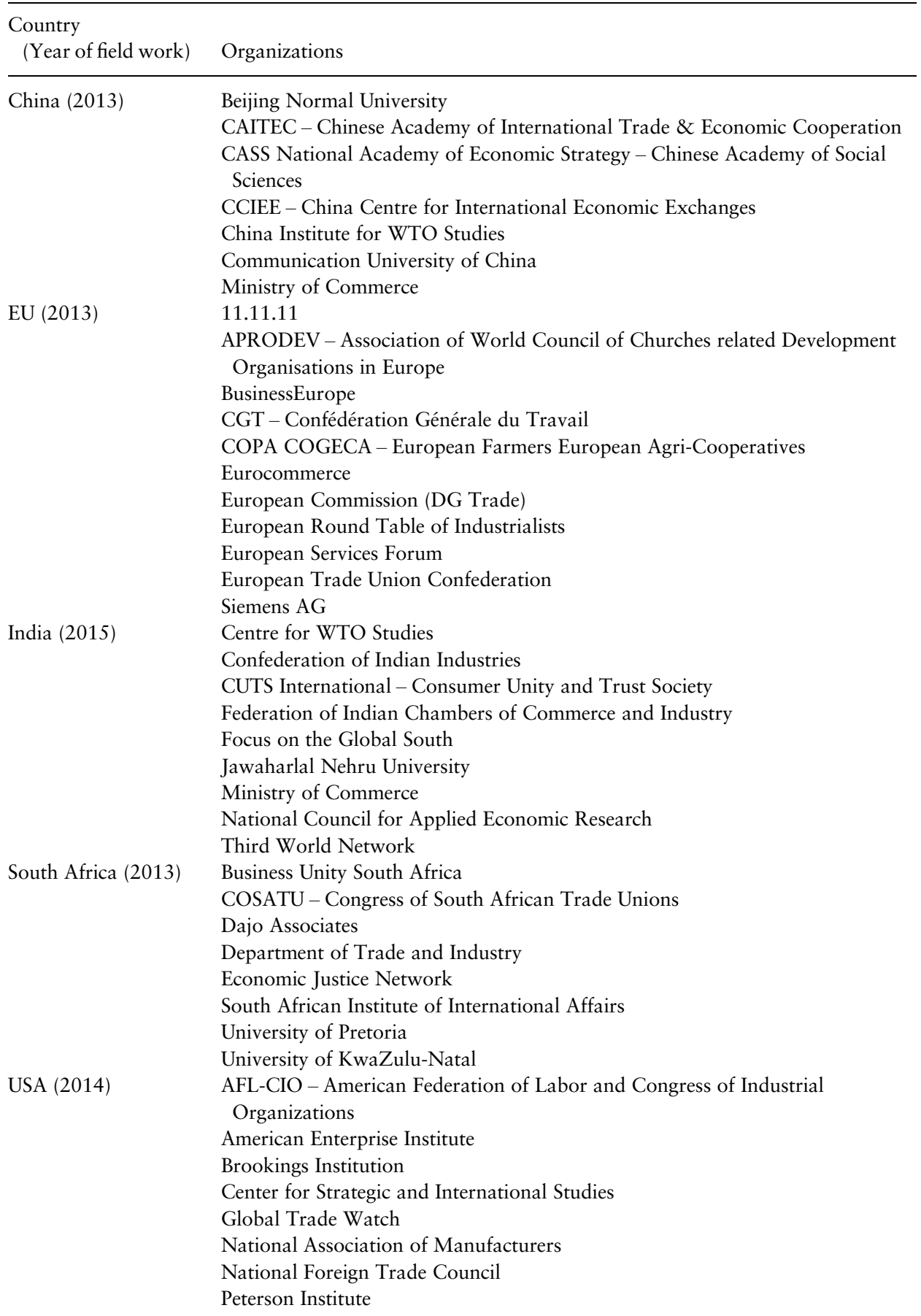


Appendix 1: (Cont.)

\begin{tabular}{ll}
\hline $\begin{array}{l}\text { Country } \\
\text { (Year of field work) }\end{array}$ & Organizations \\
\hline & Steptoe \& Johnson \\
& United States Trade Representative Office \\
& US Chambers of Commerce \\
& ICTSD - International Centre for Trade and Sustainable Development \\
& ITUC - International Trade Union Confederation \\
& IUF - International Union of Food Workers \\
& South Centre \\
& World Bank \\
& WTO Secretariat \\
\hline
\end{tabular}

